The Biology of Chameleons 
This page intentionally left blank 


\section{The Biology of Chameleons}

Edited by KRYSTAL A. TOLLEY and ANTHONY HERREL

甲

UNIVERSITY OF CALIFORNIA PRESS

Berkeley Los Angeles London 
University of California Press, one of the most distinguished university presses in the United States, enriches lives around the world by advancing scholarship in the humanities, social sciences, and natural sciences. Its activities are supported by the UC Press Foundation and by philanthropic contributions from individuals and institutions. For more information, visit www.ucpress.edu.

University of California Press

Berkeley and Los Angeles, California

University of California Press, Ltd.

London, England

(C) 2014 by The Regents of the University of California

Library of Congress Cataloging-in-Publication Data

The biology of chameleons / edited by Krystal Tolley and Anthony Herrel.

pages $\mathrm{cm}$.

Includes bibliographical references and index.

ISBN 978-0-520-27605-5 (cloth : alk. paper)

I. Chameleons. I. Tolley, Krystal. II. Herrel, Anthony.

QL666.L23в56 20I3

$597 \cdot 95^{\prime} 6$ - dc23

2013026609

Manufactured in the United States of America

$\begin{array}{llllllllll}22 & 2 \text { I } & 20 & \text { I9 } & \text { I8 } & \text { I7 } & \text { I6 } & \text { I5 } & \text { I4 } & \text { I3 }\end{array}$

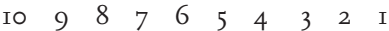

The paper used in this publication meets the minimum requirements of ANSI/NISO Z39.48-I992 (R 2002) (Permanence of Paper). @

Cover illustration: Trioceros johnstoni from the Rwenzori Mountains, Uganda. Photo by Michele Menegon. 